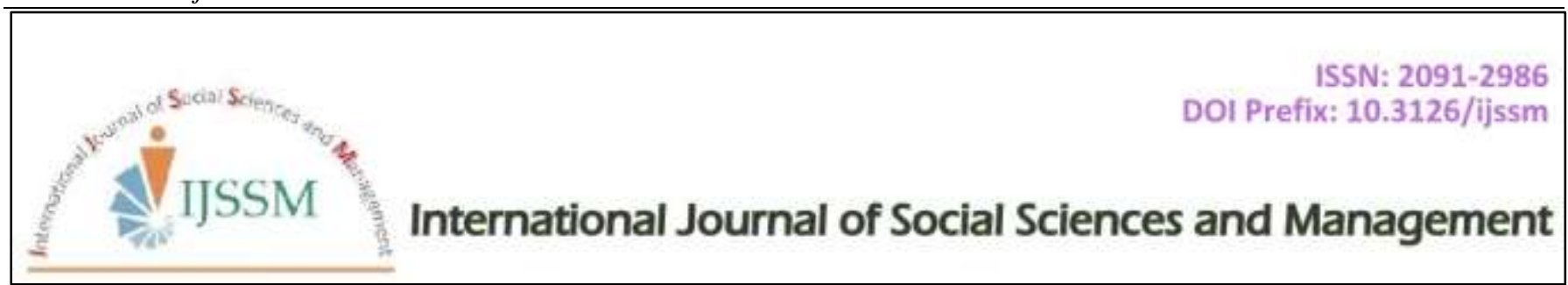

\author{
Research Article
}

\title{
The Development of Accelerated Learning System to Enhance Motivation in Business English Learning for Undergraduate Programs
}

\author{
Saowanee Thapphet*, Apipa Prachyapruit and Varaporn Bovornsiri \\ Department of Educational Policy Management and Leadership, Faculty of Education, Chulalongkorn University, Thailand. \\ ${ }^{*}$ Corresponding author email: micle2001@yahoo.com
}

\begin{abstract}
This research aimed to 1) analyse the situations and problems of Business English instruction, 2) examine the accelerated learning system to enhance motivation in Business English learning for undergraduate programmes by means of a focus group of 10 people, and 3) evaluate the accelerated learning system to enhance motivation in Business English learning for undergraduate programmes. The sample consisted of 30 Chairs of Management, the focus group with 10 experts, and the experimentation with 34 students, while the three steps of the research process included 1) the examination of concepts and theories, 2) the learning system development, and 3) the learning system experimentation. The data were analysed using percentages, mean, standard deviation, and t-test (dependent samples), and the paired difference was analysed using LSD and one-way analysis of variance. According to the results of the learning system development, the system consists of the following components: 1) input, 2) process, and 3) output and feedback. Meanwhile, the system process elements include the: 1) principles, 2) objectives and 3) evaluation and assessment of training, contents, training activities, and roles of instructors and learners. The learning system evaluation results reveal that the pre- and post-trial difference of learners' Business English knowledge to be at the statistical significance level of .05. Also, the pre- and post-trial motivation was different with an increase at the statistical significance level of .05 . With respect to the level of satisfaction towards the learning system, the learners' satisfaction towards the learning system was found to be at the highest level.
\end{abstract}

Keywords: Business English System Instruction; Accelerated Learning; Rajabhat University in Thailand.

\section{Introduction}

Thailand and the other countries in the Association of Southeast Asian Nations (ASEAN) became the ASEAN Economic Community (AEC) at the very end of 2015. However, a number of research studies indicate that Thai students encounter numerous problems when using the English language. Some publications have indicated that the ability of Thai people to use the English language is lower than most other countries in ASEAN. For example, the JobStreet. com English Language Assessment ( JELA) results showed that the country with the highest average score in English was Singapore, while Thailand was in the lowest rank (Jobstreet English Language Assessment, 2012). The survey results of the World Economic Forum (2011) revealed that the ability to use the English language of Thai people was in the $8^{\text {th }}$ rank out of ten, followed by the Lao People's Democratic Republic and the Republic of the Union of Myanmar. Furthermore, the survey results of the international organization EdF (Education First, 2013), which measured the English language proficiency of adults in various countries around the world, found that Thailand was in the last rank of 60 countries worldwide. The main problem with teaching and learning English in Thailand is that the teaching methods emphasize grammar with very little listening and speaking practice.

In addition, Thailand also has problems with Business English skills development in order to be equal to other countries in ASEAN. A number of research studies found that Thai students lack business communication skills. For example, the research of Ates ( 2012) illustrated that students studying Business Administration are required to develop problem- solving skills, analysis and synthesis skills, and to understand and have an awareness of the current commercial world by using learning approaches 
such as group work, case studies, and participatory learning, in order to allow the learners to chat, read, write, and express their ideas as well as deal with business problems, and develop Business English language skills. Meanwhile, the Business Administration curriculum in Thailand faces a problem with speaking English. For example, the undergraduate students in the Faculty of Management Science at Kasetsart University, Si Racha Campus lack Business English speaking skills and self- confidence (Nongsamorn, 2011). This is because they have insufficient knowledge of basic English for communication, limited vocabularies, and a lack of language usage skills in the actual community, as well as weakness in analytical thinking and the capability to give rational explanations to support their ideas. Moreover, the research also found that the courses with constant actual practice under the recommendations for weakness correction of individuals can build confidence and develop speaking ability.

At present, to operate a business requires an understanding of cultural diversity ( Yamazaki \& Kayes, 2004; referred to in Ates, 2012), world markets, and customers worldwide. Firms and organisations need personnel who have an educational background in Business and understand the perspectives at the national level, and therefore are able to develop their decision-making skills. Learning approaches can assist the learners with understanding cultural diversity and with being able to apply this concept to conducting international business ( Jain, 2009; referred to in Ates, 2012). These approaches include methods such as cooperative learning, peer-assisted learning, teaching and learning media discussion, problem solving, report writing, and presentations. With these methods, the learners will gain experience in English for Specific Purposes (ESP(. Learning through case studies using actual real-life contexts allows the learners to understand and recognise the language. Discussion and writing skills are also necessary for the learning process.

If the learners would like to learn English efficiently, they need to have the motivation throughout the learning period, so that they will be enthusiastic to pursue knowledge; these are classified as the intrinsic motives. Takase (2007; referred to in Chumcharoensuk, 2012) explained that intrinsic motives are related to the will to learn, the enjoyment and interest of the students, and the need to be a part of the environment. Another type of motive includes the extrinsic motives, which fulfil the needs of individuals, for example money, jewellery, houses, food and other items that facilitate daily life. For this reason, both types of motives are necessary for foreign language learning such as English, particularly the intrinsic motives.

Currently, one important learning technique is used to create motives for learners, which is implemented to improve English language teaching and learning. Students will not have the motives to learn if the content of writing English is not interesting and is not linked to the subjects that they study. As a result, the teachers consider that the students do not prepare themselves for the teaching and lessons before the communication practice in class.

This approach takes a short amount of time, reduces the cost of teaching and learning, emphasizes in- depth learning rather than superficial learning (Light and Cox, 2001), and enhances the relationship between learners and teachers. It is consistent with the English teaching and learning methods that focus on interactive skills, which include both receptive skills and productive skills. To implement this technique in studying vocabulary, it was found that when the students learnt 1,400 vocabulary words per month in learning French and Hindi, it helped to enhance the efficiency of their memory by $50 \%$. In German language learning, it was found that almost half of the learners had a better memory. Furthermore, this technique is also used to learn other languages such as French, Spanish, Italian, and German. In teaching, Baroque music and psychological techniques are used to create the connection. Learning will be more successful if the learners learn the language along with the original language. This is because 1) it is easy for the connection, and 2) it is easier to remember the new vocabulary. To think about the vocabulary when it is needed to be used is the method to explain the Second Language theory. This is the theory that allows the learners to understand the content and has the content that is interesting to the learners. If the content only focuses on teaching grammar, it might be inappropriate. On the other hand, with the use of the accelerated learning approach, the learners will acquire the language from practical communication (Rose, 2003).

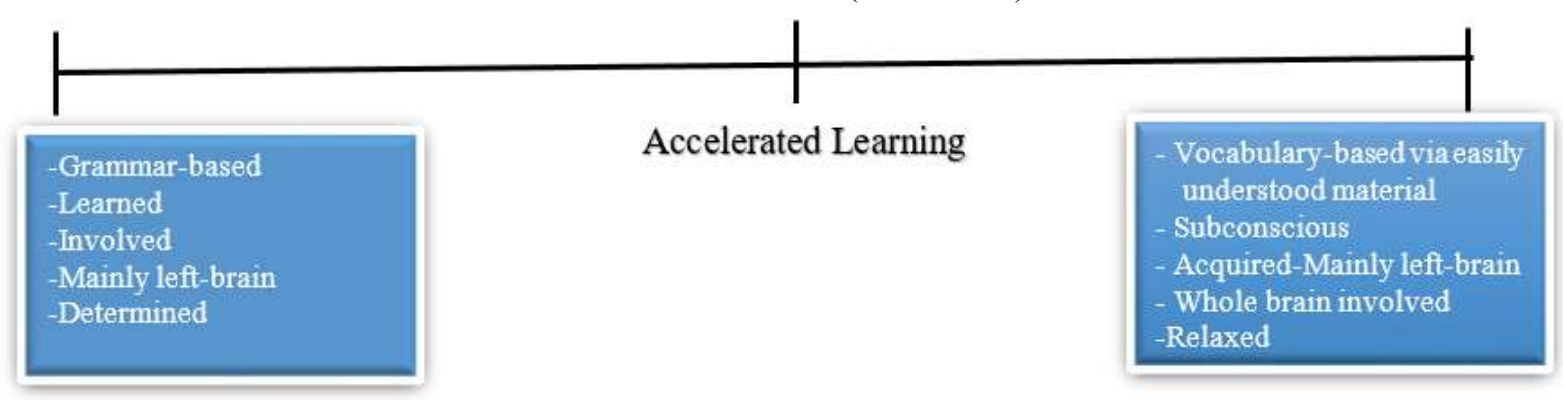

Fig. 1: Spectrum bar showing learning and language acquisition and accelerated learning Source: Rose )2003(.

Fig. 1 illustrates the relevant research on the second language acquisition, which is an interesting matter because it involves the answer to the question of how humans acquire language. Language acquisition from what has been provided to learners gives importance to the message rather 
than the form. This hypothesis is practical with both children and adults, since the act of listening for understanding is fundamentally important to language acquisition, as it will result in speaking skills. Acquisition will be activated when there is a conversation between a speaker and a listener and the listener understands the message. If the receiver understands the message, their speaking skills will develop later. Grammar-based teaching is on the far left of the spectrum bar, while the meaning input and language acquisition are on the far right.

Accelerated learning is also on the right. Language learners and receivers will develop language more easily if they feel relaxed while learning.

Scott )2003( suggested that accelerated learning should be implemented at the higher education level since it would be beneficial for the students, teachers, and learners, as well as to lifelong learning. In general, this learning approach is implemented in special sections of teaching and learning )weekend and evening classes(. However, the researcher applied it to the normal section in order to create the innovations and adapt the system to be appropriate with the normal educational programmes. Moreover, Prayad (2010) added that, according to the literature of the past 3 to 5 years, there were no published review articles related to accelerated learning in the Thai language.

The advantages of accelerated learning are that it is helpful in generating the creative thinking rather than to using the memorization of teaching materials, and that it is focused on a class atmosphere that is open to discussion and class participation more than asking questions during the lectures (Roberts, 2006). Moreover, this learning approach is suitable with groups of diverse learners, which was consistent with the students at Songkhla Rajabhat University where some students are Thai-Muslim, and enhances learning motivation for the learners (Walker et al., 2008).

Therefore, the researcher was interested in developing an accelerated learning system to create the motives in English learning for undergraduate students in order to improve the English teaching and learning system that would motivate the learners and would be beneficial for the development of labour skills that are necessary for the AEC labour market.

This would assist the students that have graduated in the field of Business Administration to earn a living efficiently and effectively within an organization, as well as to fulfil the requirements of the domestic and international labour markets.

\section{Materials and Methods}

The sample group was 30 Chairs of Management selected by purposive sampling, 10 experts from the group meeting, and 34 third-year students who were taking the Business English course in the General Management Programme of the Faculty of Management Science, Songkhla Rajabhat University. The interview form, the evaluation form of the accelerated learning system for English language for graduate students, the English learning satisfaction evaluation form, the motives measurement form, and the objective test were used as research tools. The research process was as follows: 1( study of the theories from the literature, 2( study of the general state and problems of Business English learning by interviewing the executives, 3 ( evaluation of the system by setting the focus group, and 4( trial of the system with students in the Management Programme who were taking the subject Business English 1 at the Faculty of Management Science, Songkhla Rajabhat University using content analysis and mean analysis, frequency, and t-test.

\section{Results and Discussions}

The findings show that the situation and problems of Business English instruction comprises the following: 1) There is a need to promote more English foundation skills for competitiveness among university groups. 2) Curriculum content is not specific to the field of management, and should be more focused on business content more. 3) Teachers must meet the requirements set by the institutions. 4) Learners must develop basic knowledge of English and have a positive attitude towards the subject. 5) There should be a variety of measurements and assessments. 6) The institutions should encourage cooperation with enterprises. 7) Teachers should develop techniques for teaching methods to motivate students more. 8 ) The media is not modern enough and is insufficient.

In addition, the findings show that the learning system consists of input, process, outcome, and feedback. The intrinsic motives include the executives, teachers, students, environment, equipment and teaching aids, teaching plans, teaching approaches, and English language learning and teaching policies. These results are in accordance with previous surveys that demonstrated that 1) learners have basic English language skills in all four areas, including listening, speaking, reading and writing, that are insufficient for studying English for Specific Purposes and learners lack confidence in presenting information. Furthermore, learners lack motivation in their studies. Regarding the curriculum of the courses, 2) there is no analysis of the needs of the learners, and there is a lack of appropriate curriculums and textbooks, 3) regarding teachers, it can be seen that there are no native speakers to provide knowledge of correct pronunciation in lessons about talking on the telephone and responding to e-mail messages, 4) the organisation of the lessons lacks the 
arrangement of an atmosphere that is appropriate to the level of study, and 5) there is a lack of modern educational technology (Ünal, 2014). 2). The teaching and learning process which is comprised of the principles of Business English, the objectives of Business English learning, the Business English learning process, the teaching components and atmosphere, and the pre- and post-evaluation, 3) the results from the learning system resulting in the higher achievement, motivation, and satisfaction towards learning, and 4( the feedback from the learners and the employers, were in line with the research of Warunee (2015) (Fig. 2 and Fig. 3).

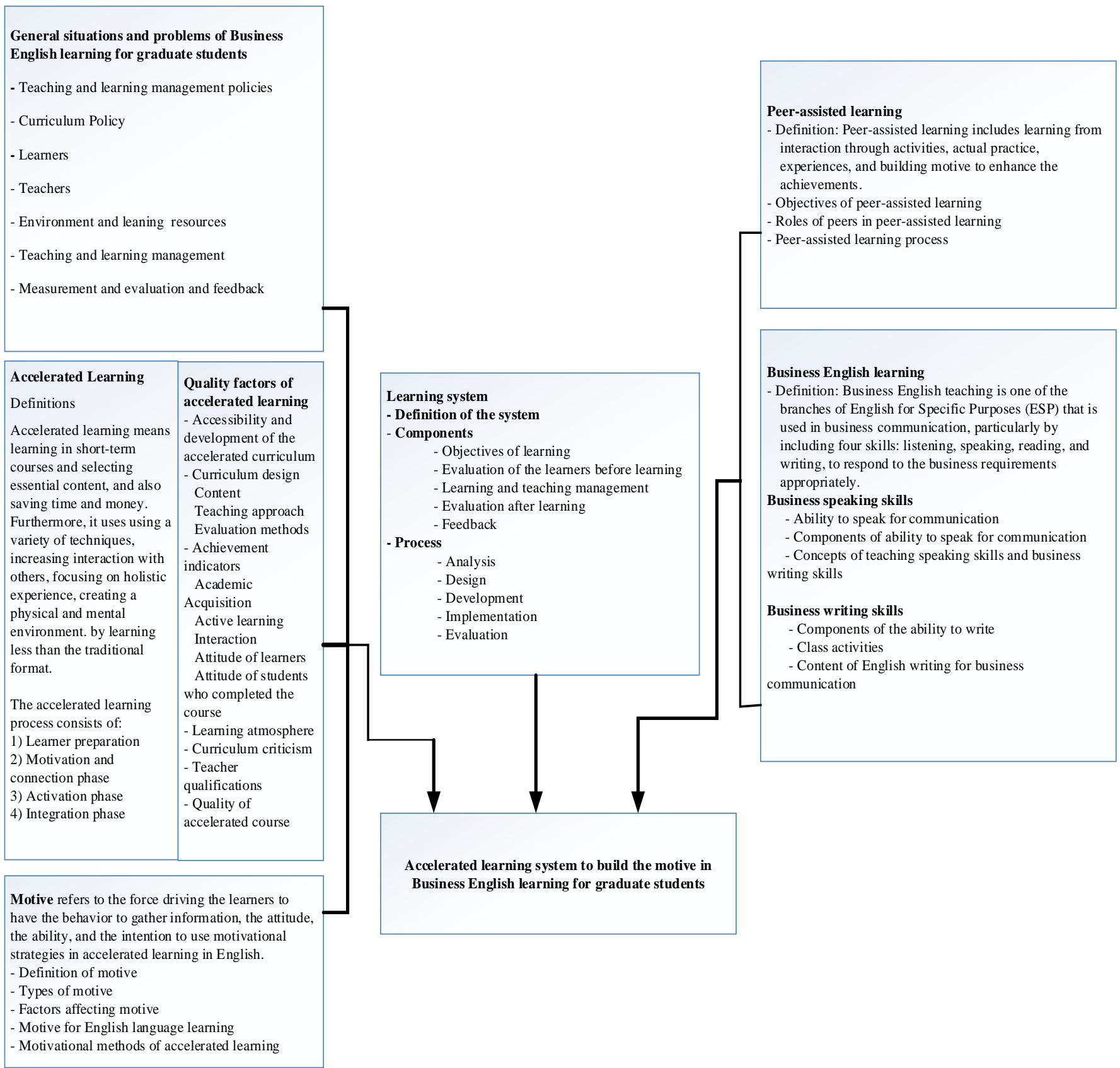

Fig. 2: Framework of the accelerated learning system to build the motive in Business English learning for graduate students acquired from the synthesis of relevant literature and theories 


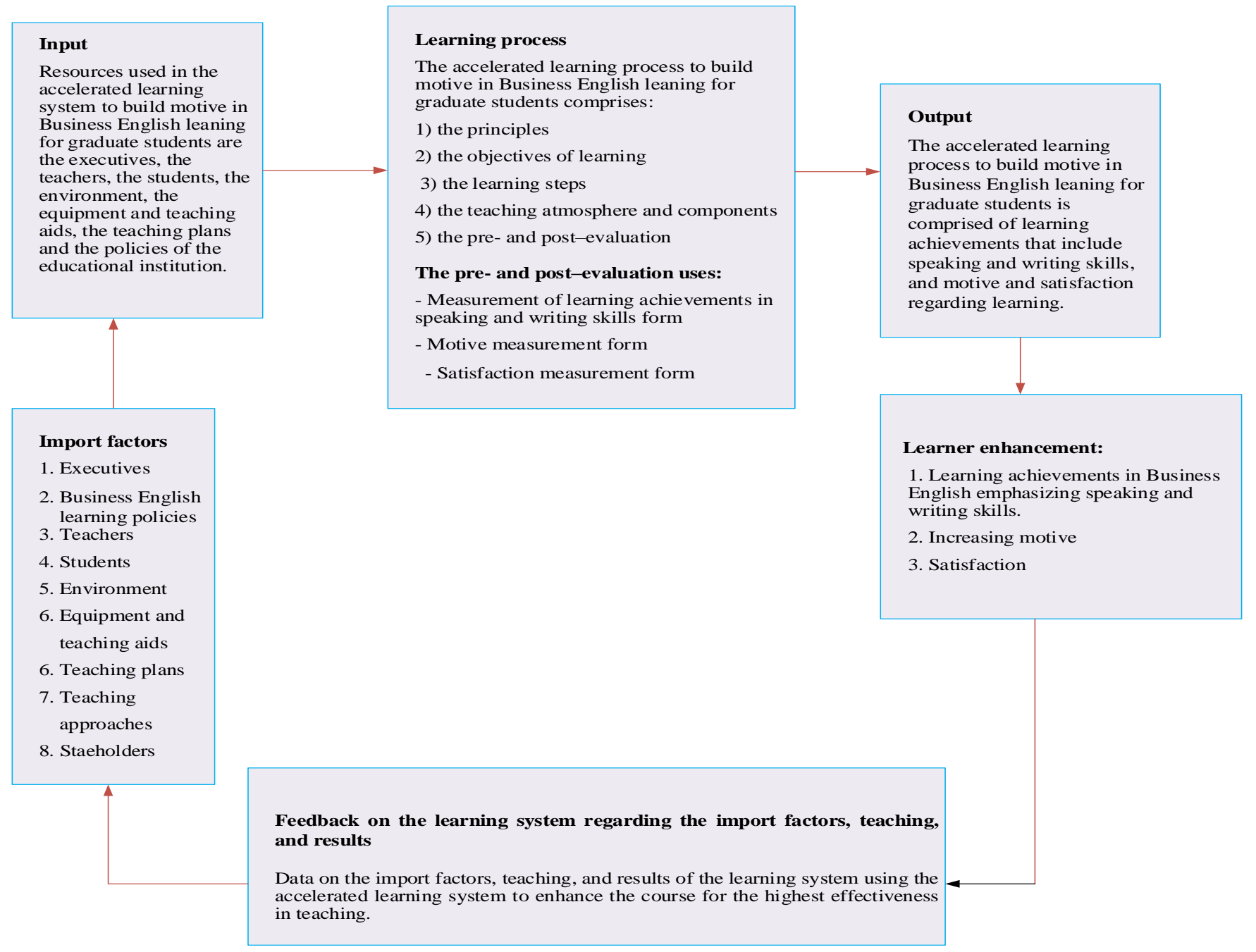

Fig. 3: Accelerated learning system to build the motive in Business English learning for graduate students acquired from the focus group interview.

Moreover, the evaluation of the accelerated learning system to build motivation in Business English learning for graduate students showed that:

1) The Business English learning achievements of the students who were taught with the accelerated learning system to build the motivation in Business English learning for graduate students, both pretrial and post-trial, were different with statistical significance at 0.5 , which was consistent with the research of Wlodkowski, J. R. and Kasworm, C. E. )2003( )Fig. 4(.

2) 2) The students who were taught with the accelerated learning system to build the motivation in Business English learning for graduate students were different with statistical significance at 0.5 , which was consistent with the research of Wlodkowski, J. R. and Kasworm, C. E. (2003) (Figure 5).
3) 3) The level of satisfaction of the students who were taught with the accelerated learning system to build the motivation in Business English learning for graduate students after the trial was at the highest level (Figure 6).

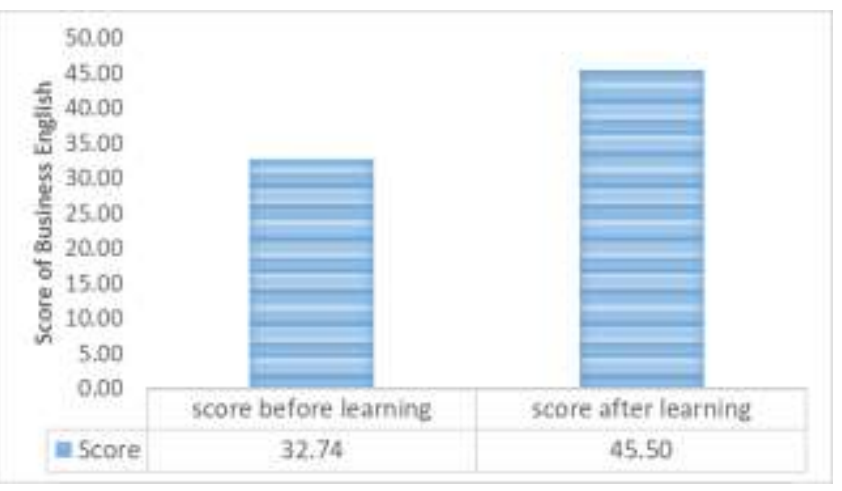

Fig. 4: Comparison of scores before and after learning with the accelerated learning system to build the motive in Business English learning for graduate students. 


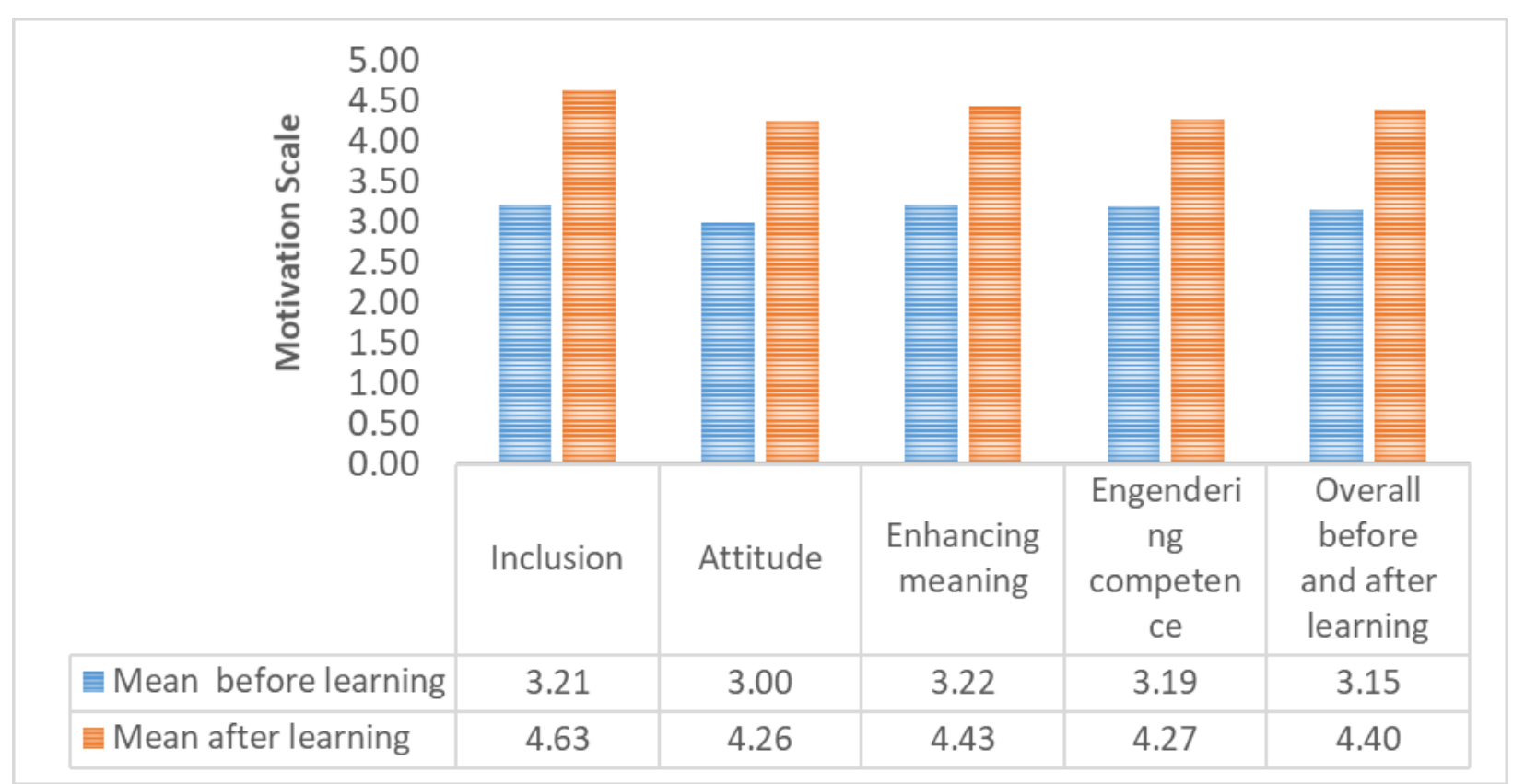

Fig. 5: Comparison of mean of motive by aspect before and after learning and the overall average before and after learning.

Source: Questionnaire adapted from Wlodkowski )2011(

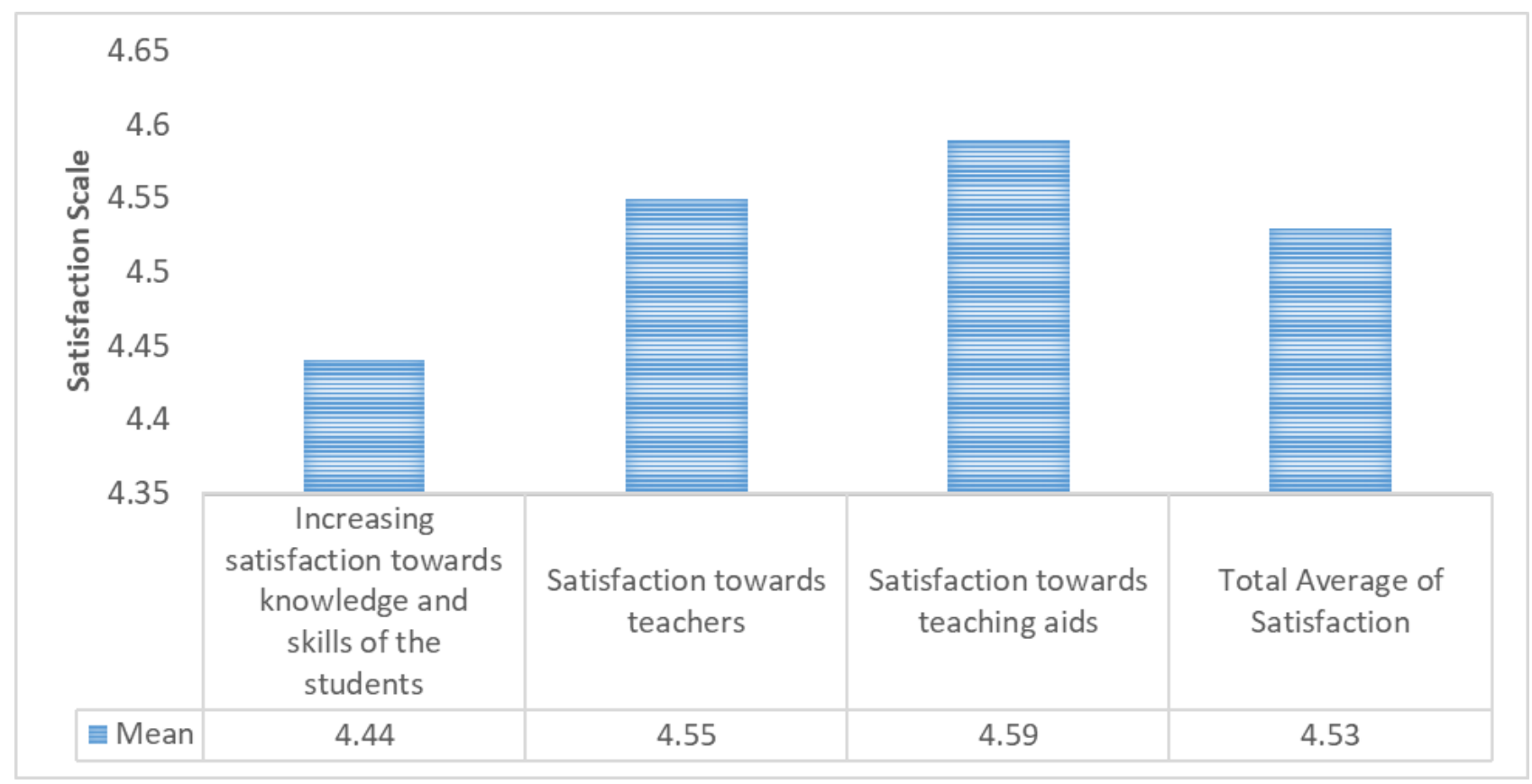

Fig. 6: Mean of satisfaction by aspect and the overall average towards the accelerated learning system to build the motive in Business English learning for graduate students.

\section{Acknowledgements}

This study was supported by my advisor Assistant Professor Dr. Apipa Prachyapruitt and my co- advisor Associate Professor Dr. Varaporn Bovornsiri from the Faculty of Education, Chulalongkorn University. Furthermore, the author acknowledges the financial support of the Office of the Higher Education Commission.

\section{References}

Ates O )2012( Impact of case study method on an esp business course. International Journal of Business and Social Science 3: 135-140. 
Chumcharoensuk N ) 2013( A comparative study of English learning motivation types between Thai and Cambodian first- year undergraduate English majors ) Doctoral dissertation, Language Institute, Thammasat University(.

Education First ) 2013( English Language Proficiency Examination] Online[ . Available from: http: www.ef.co.th/epi ]24 November 2013[

JELA ) JobStreet English Language Assessment( ) 2013( Thailand's English skills lowest in SEA. The Nation )June 11,2013 .

Light G and Cox R ) 2001( Learning and teaching in higher education: The reflective professional. London: Sage.

Nongsamorn P )2011( The study of problems of speaking English in verbal communication of students. Faculty of Management Science Kasetsart University Sri Racha Campus Journal of the Humanities 18: 85-97.

Prayad J ) 2010( Accelerated learning: An interesting learning strategy. Journal of Education 21: 1-8.

Rose C )2003( Accelerated learning ] Online[. Available from: http://stimul.az/downloads/Accelerated_learning.pdf $] 8$ July 2013[
Scott PA )2003( Attributes of high-quality intensive courses. New Directions for Adult and Continuing Education 97: 29-38.

Ünal A )2014( The Problems Encountered In English For Specific Purposes: Business Department Case. The Clute Institute International Academic Conference. Germany: Munich, 414-421.

Warunee S, Apipa P and Varaporn B )2015( Development of a mentoring system for developing faculty members, ability to do classroom action research at colleges of nursing under praboromarajchanok. Institute, the ministry of public health. Journal of Nursing and Education 8: 67-82.

Wlodkowski JR and Kasworm CE ) 2003( Special issue: accelerated learning for adults: The promise and practice of intensive educational formats . New Directions for Adult and Continuing Education 97: 1-98.

Wlodkowski RJ and Ginsberg MB )2010( Teaching Intensive and Accelerated Courses: Instruction that Motivates Learning. San Fransisco: Jossy Brass.

World Economic Forum ) 2011( Proceedings of the global competitiveness report 2011-2012, Geneva Switzerland. 